\title{
SETD7 Gene
}

National Cancer Institute

\section{Source}

National Cancer Institute. SETD7 Gene. NCI Thesaurus. Code C73667.

This gene is involved in epigenetic control of gene expression. 